\title{
The impact of flood on the socio-economic status of residents of Wadata and Gado-villa communities in the Makurdi metropolitan area of Benue State, Nigeria
}

\author{
R. G. Awopetu ${ }^{1}$, S. O. Awopetu ${ }^{2}$ \& M. S. Awopetu ${ }^{3}$ \\ ${ }^{I}$ Department of Psychology, Benue State University, Nigeria \\ ${ }^{2}$ Nigeria Petroleum Development Company Ltd. (A subsidiary of NNPC) \\ Edo State, Nigeria \\ ${ }^{3}$ Department of Civil Engineering, Ekiti State University, Nigeria
}

\begin{abstract}
The study examined the effect of flood on the socio-economic status of residents of Wadata and Gado-villa communities in the Makurdi metropolitan area of Benue State, Nigeria. A sample of five hundred and two (502) displaced residents consisting of males and females camped at St. Theresa Catholic and St. Catherine primary school, Makurdi participated in the study. A questionnaire consisting of six sections measuring demographic variables and impacts of flood on socio-economic status such as agriculture, education, health, housing, water and sanitation was used to collect data. The study established that flood impacted negatively on the socio-economic well-being of residents in the two communities. It is recommended that the government should provide a low-cost housing estate for the flood victims as they have expressed willingness to relocate from the flood prone area so that their children can go back to school as soon as possible. Further allocation of land for residential building in the flood prone areas should be stopped by the government and private land owners. The river banks should be converted to recreation centres and green areas. Keywords: flood, socio-economic status, residents, Makurdi, Nigeria.
\end{abstract}




\section{Introduction}

Flood is one of the natural disasters that many at times resulted in direct loss of social and economic properties, physical injuries, to the extent of psychological injuries. Natural disasters threaten lives thus causing a lot of anxieties and fear in an individual. As observed by Nasir et al. [1], socio-economic impact of flood included the loss of and destruction of properties and life, which may eventually last for a short or long term. Serious floods in Nigeria are rare events and relatively "tame" when compared with those in other parts of the world. Their psychological impacts on health vary from between population for reasons relating to population vulnerability and type of flood events (Ahern et al. [2]). In August 2012, water released from Lagdo Dam located in the northern province of Cameroon which is up-stream of River Benue lead to increase in volume of River Benue and flooded several towns and villages along its course. These include Adamawa, Anambra, Edo, Taraba, Benue, Kogi, Bayelsa and Delta. The flooding resulted in over 10 deaths and loss of properties worth several millions of naira and displaced about 131,011 people (The Nation [3]). This is not the first time of such an occurrence, but the government of Nigeria is still yet to find a solution. Governments as well as the affected communities were taken completely by surprise at the severity of the event considering the fact that flood warnings were issued by the Nigeria Metrological Agency (NMET), National Emergency Management Agency (NEMA) and Federal Ministry of Environment to local residents but no action was taken. Areas that were never thought could be flooded were completely submerged in water for days.

The socio-economic impacts refers to all changes in the way people live, work, relate, organise and how these interactions have direct influence on means of livelihood, the purchasing and production power, mass migration and agriculture. More specifically, social impacts concern poverty, loss of life, health effects, loss of community cohesion, loss of time, changing attitudes, impoverish neighbourhood etc, which are difficult to quantify in monetary terms (Messner and Green [4]). On the other hand, the economic impacts include disruptions of clean water and electricity supply, transport, communication, education, health care services, reduction in purchasing power and loss of land value in the flood plains which can lead to increased vulnerabilities of communities in the living area. The additional cost of rehabilitation, relocation of flood victims and removal of property from flood-affected areas can divert the capital required for maintaining production.

Many people experienced a number of associated problems which contributed to the levels of stress suffered, such as problems with personal relationships (at home and at work), problems with employment as well as lack of understanding and sympathy from authorities and society in general. People in employment found it particularly difficult to cope with all the arrangements that had to be made for getting the house back in order (Awopetu [5]).

Studies have shown that socio-economic impacts of floods like the wide impact-survey in Scotland (Werrity et al. [6]) and the survey on flood experience in Belgium (Grinwis and Duyck [7]) flood victims experience intangible impacts 
as being even more severe than tangible impacts. This confirms the high cost of relief and recovery which may adversely impact investment in infrastructure and other development activities in the area and in certain cases may cripple the frail economy of the communities. Recurrent flooding in a region or state/nation may discourage long- term investments by the government and private sector alike. Lack of livelihoods, combined with migration of skilled labour and inflation may have a negative impact on a nation's economic growth. Loss of resources can as well lead to high costs of goods and services, delaying its development programmes.

The social economic impacts are experienced by different people in different ways. Against this background, therefore, this paper aims at assessing the impact of flood on socio-economic status of residents in two communities affected by the 2012 Makurdi flood, in Benue State, Nigeria.

\section{The study area}

Makurdi Metropolitan area is the capital city of Benue State and is located in the middle belt region (north-central) of Nigeria $\left(6^{\circ} 45^{\prime}-8^{\circ} 15^{\prime} \mathrm{E}, 7^{\circ} 30^{\prime}-9^{\circ} 45^{\prime} \mathrm{N}\right)$. It has a population of 297,398 spread out over an area of $41,035 \mathrm{~km}^{2}$ making it the most densely populated local government area in Benue State, with a mean of 257 people per $\mathrm{km}^{2}$. It has a diverse cultural make-up, among which the following ethnic groups are prominent: Tivs, Idomas, Igedes, Hausas, Yorubas and Ibos (National Population Census [8]).

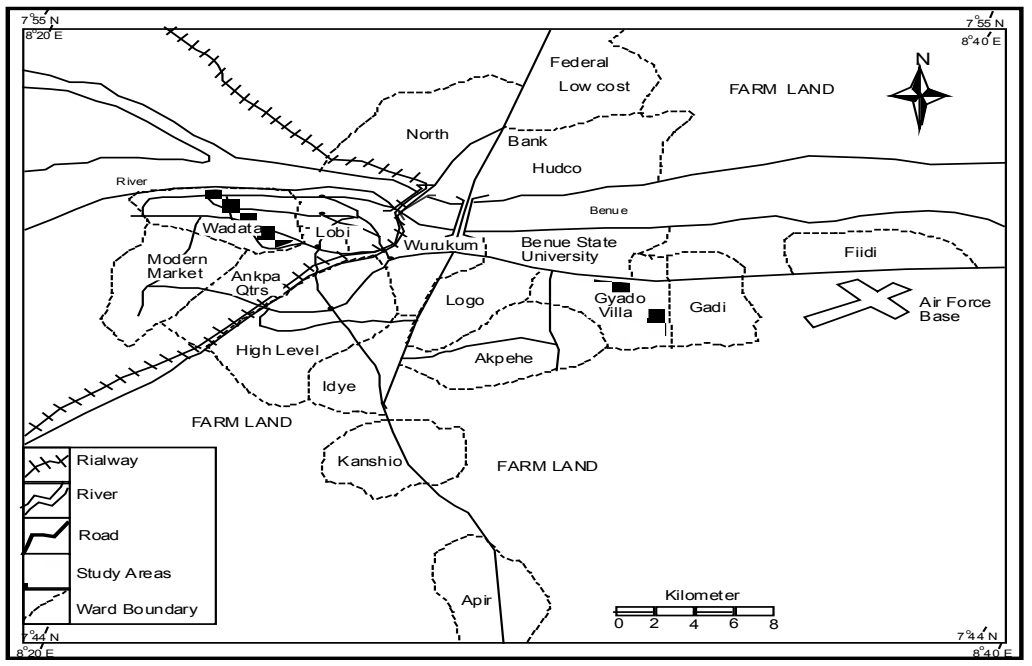

Figure 1: $\quad$ Map of the study area. 


\section{Method}

The study which employed quantitative approach used sample consisted of victims of 2012 Makurdi flood. The victims were camped at St. Catherine and St. Theresa primary schools. A sample size of five hundred and two (502) victims participated in the assessment survey. A purposive sampling was adopted, this is because, according to Strydom et al. [9], purposive sampling is entirely based on the judgment of the researcher, in that a sample is composed of elements that contain the most characteristics, representative or typical attributes of the population.

\subsection{Instruments}

The instrument for the study was a household questionnaire. The questionnaire consisted of six sections measuring demographic variables and impacts of flood on socio-economic status such as agriculture, education, health, housing, water and sanitation is used to collect data. Section A measures demographic variables, section $\mathrm{B}$ measures flood impact on agriculture, section $\mathrm{C}$ measures flood impact on education, section D measures flood impact on health, section $\mathrm{E}$ measures flood impact on housing and section $\mathrm{F}$ measures flood impact on water and sanitation.

\subsection{Procedure}

A copy of each questionnaire was given to the respondents at the relief camps. Five hundred and fifty questionnaires were administered to the respondents, by the time of retrieval; only five hundred and two were retrieved due to inappropriate fillings of some of the questionnaires.

\subsection{Data analysis}

Simple percentages and frequency were used in analysing the data.

\section{Results and discussion}

Often mostly affected by natural disaster such as flood are women and children. More than half of the respondents interviewed (52.2\%) were female and more than 8 out of every 10 respondents interviewed are married (Table 1). Health and sanitation was a big issue. The two camps set up in a government own schools had no bathing facility. Whereas the men and young children can take baths outside on the school lawn, women do not have that option. Many people did not have a chance to pick up their belongings when the floods hit their houses so they have no change of clothes. Many are wearing what they left home in and without being able to wash and women's hygiene in particular has deteriorated. The situation is even worse for menstruating and pregnant women.

Also from table 1, it can be seen that respondents age were categorized into five different age groups and the greater proportion of respondent falls between 
the age group 26-30 (30.3\%) followed by age group 41 and above with $24.7 \%$, age group 31-35 accounted for $18.9 \%$ of the respondents, age group 18-25 accounted for $13.1 \%$ of the respondents and age group 36-40 is the closest age group to the least age group with the total of $12.9 \%$. From the data above, it is crystal clear that adults in their productive age (26-40 years), which form $62.1 \%$ of the respondents, are affected by the flood. This will impact negatively on the economy of the study area most especially when a large percentage of the respondents are self employed (figure 2).

Table 1: Percentage distribution of respondent's socio-demographic characteristics.

\begin{tabular}{|l|l|l|}
\hline Variables & Frequency & Percentage \\
\hline Respondent's marital status & 404 & 80.5 \\
\hline Married & 66 & 13.1 \\
\hline Single & 32 & 6.4 \\
\hline Divorced & 502 & 100.0 \\
\hline Total & \multicolumn{2}{|l|}{} \\
\hline Respondent's sex & 240 & 47.8 \\
\hline Male & 262 & 52.2 \\
\hline Female & 502 & 100.0 \\
\hline Total & 66 & 13.1 \\
\hline Respondent's age group & 152 & 30.3 \\
\hline $18-25$ & 95 & 18.9 \\
\hline $26-30$ & 65 & 12.9 \\
\hline $31-35$ & 124 & 24.7 \\
\hline $36-40$ & 502 & 100.0 \\
\hline 41 and above & \multicolumn{2}{|l}{} \\
\hline Total &
\end{tabular}

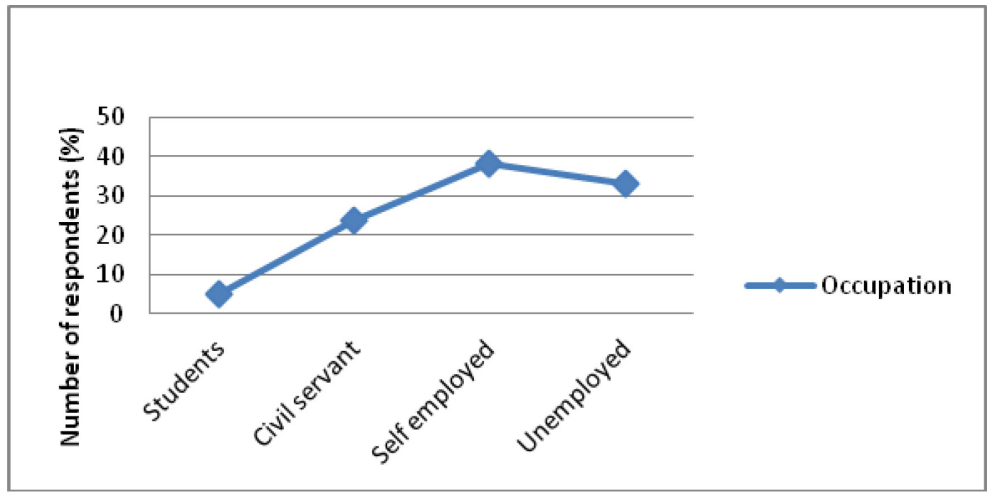

Figure 2: Occupational status of the respondents. 


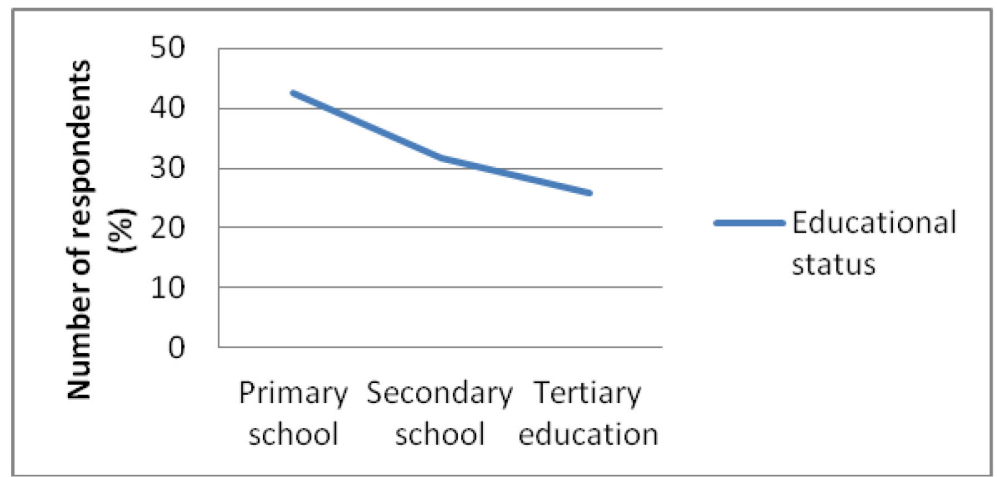

Figure 3: Educational status of the respondents.

Furthermore, the figure 3 shows that slightly above 4 in every 10 respondents are reported to have primary education $(42.4 \%)$ which implies that the majority of the respondents interviewed have primary education, followed by the respondent who reported to have secondary education $(31.7 \%)$, while the respondents with tertiary education has the least percentage $(25.9 \%)$. The educational statuses of the respondents are low but it cannot be generalised that the educational status of the people that are affected by the flood are generally low. This is because, flood affected people with high educational status are either gainfully employed and therefore can afford to pay for temporary accommodation or relocate to live with friend temporarily.

The 2012 flood has inflicted severe direct and indirect damages on social; infrastructure and economic sectors of Makurdi metropolis. Close to half of the respondents $(48.0 \%)$ reported that their houses were collapsed. About 12,000 people were displaced from their dwelling. A high number of deaths was not

Table 2: Percentage distribution of respondent's response on the impact of flood on agriculture.

\begin{tabular}{|l|l|l|}
\hline variables & frequency & Percentage \\
\hline Household experienced crop damage as a result of flood \\
\hline Yes & 342 & 68.1 \\
\hline No & 160 & 31.9 \\
\hline Total & 502 & 100.0 \\
\hline \multicolumn{2}{|l|}{ The main staple crop damaged as a result of flood } \\
\hline Yes & 360 & 71.7 \\
\hline No & 142 & 28.3 \\
\hline Total & 502 & 100.0 \\
\hline Household experienced loss of food stock as a result of flood \\
\hline Yes & 481 & 95.8 \\
\hline No & 21 & 4.2 \\
\hline Total & 502 & 100.0 \\
\hline
\end{tabular}




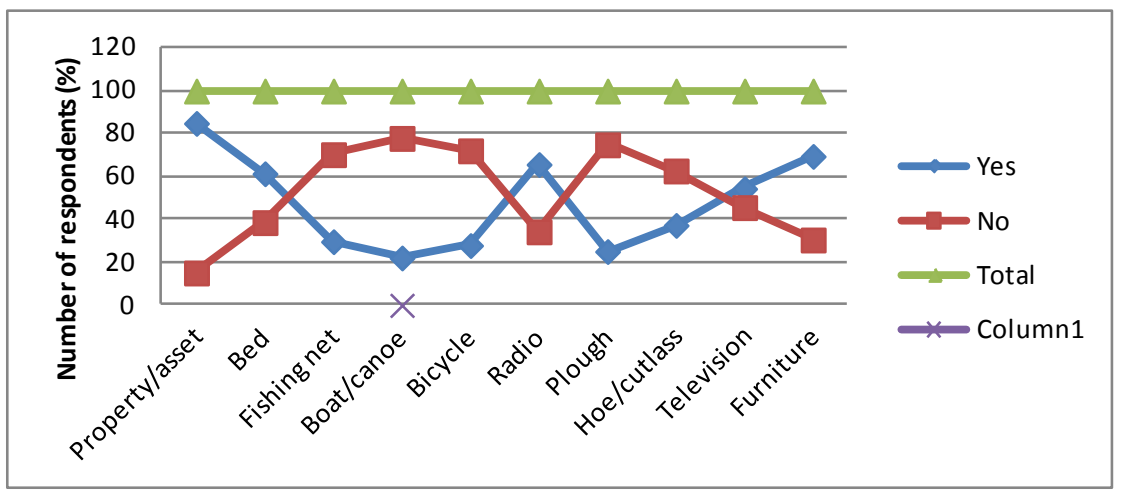

Figure 4: Percentage distribution of respondent's response on the impact of flood on housing/property/assets.

recorded because the flood gradually hit the town while people were opportune to remove some of their movable belongings. In spite of this, many people lost their fishing nets, canoes, furniture, electronics and plough (figure 4). It was also revealed from table 2 that close to 7 in every 10 respondents $(68.1 \%)$ reported that their household experienced crop damage as a result of flood. More than 7 in every 10 respondents $(71.7 \%)$ reported that their main staple crop was damaged as a result of flood. Similarly, majority of the respondents $(95.8 \%)$ reported that their household experienced loss of food stock as a result of flood.

It can be seen from figure 5 that the educational facilities such as school buildings, learning material such as books and furniture were also affected. Worse still, majority of the respondents $(73.1 \%)$ revealed that school going children in their household experience disruption in learning activities as well as school attendance for about three months due to the flood. More so, the table revealed that more than half of the respondents $(53.6 \%)$ reported that road being impassable is the main reason why children in their household experience disruption in an attendance Also, revealed in figure 5 is that $44.6 \%$ of the respondents reported that bridge culvert washed away or submerged is the main reason why children in their household experience disruption in an attendance while $60.8 \%$ of the respondents reported that school submerged/surrounded by water is the main reason why children in their household experience disruption in an attendance.

* Educational facilities is available in your area

** School infrastructures were damaged due to flood

*** School going children in your household experience any disruption in an attendance due to the flood

**** Road impassable is the main reason why children in your household experience any disruption in an attendance 
***** Bridge culvert washed away or submerged is the main reason why children in your household experience any disruption in an attendance

$* * * * * *$ School submerged/surrounded by water is the main reason why children in your household experience any disruption in an attendance

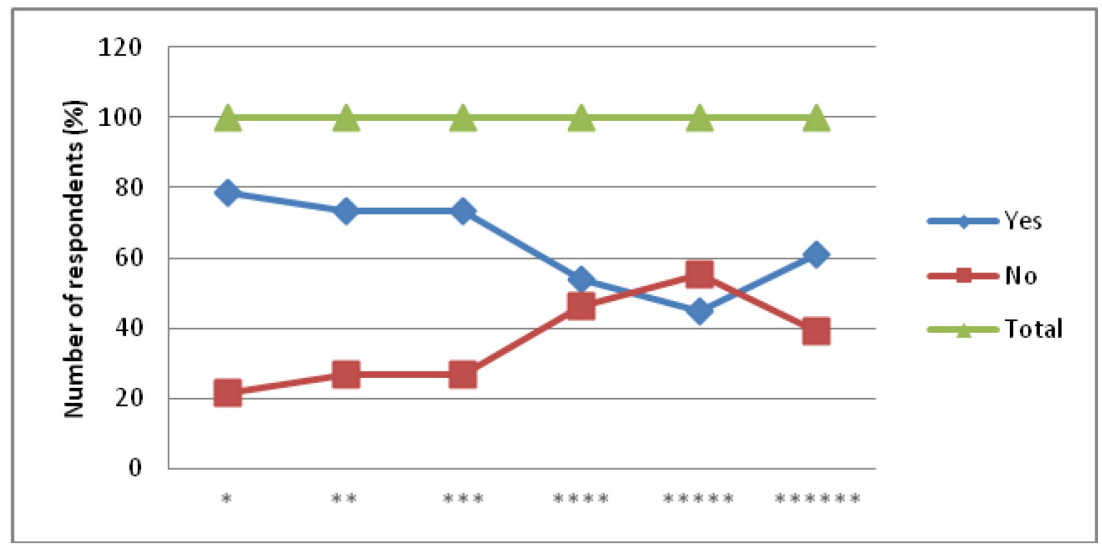

Figure 5: Percentage distribution of respondent's response on the impact of flood on education.

Health care facilities were not left out in the flood disaster. From figure 6, it can be seen that $61.2 \%$ of the respondents reported that health facilities available in their area where damaged due to flood. More than 6 in every 10 respondents $(63.1 \%)$ reported that there is disruption in access to health service as a result of the flood. Furthermore, the figure 6 revealed that more than 8 in every 10 respondents $(81.5 \%)$ reported that their household members get sick during the flood while $9.4 \%$ of the respondent specifically reported that diarrhea were experienced by their household member who got sick.

It can be seen from Table 3 that the majority of the respondents $(25.5 \%)$ reported that river water is the common source of their drinking water, $21.1 \%$ of the respondents reported that protected well is their common source of drinking water while $18.3 \%$ and $16.5 \%$ of the respondents reported that borehole and unprotected respectively well are their common source of their drinking water. Close to 9 in every 10 respondents revealed that their source of water are affected by the flood while $13.1 \%$ of the respondents disagreed with the fact that source of water are affected by the flood.

Also, the majority of the respondents $(69.5 \%)$ reported that traditional pit latrine is the type of sanitary facilities available in their area, $18.9 \%$ of the respondents reported that reticulated sewerage is the type of sanitary facilities available in their area while $10.0 \%$ and $1.6 \%$ of the respondents reported that VIP and others respectively are the type of sanitary facilities available in their area. More than 9 in every 10 respondents revealed that their sanitary facilities affected by the flood water while $4.8 \%$ of the respondents disagreed with the fact that sanitary facilities affected by the flood water in their area. 


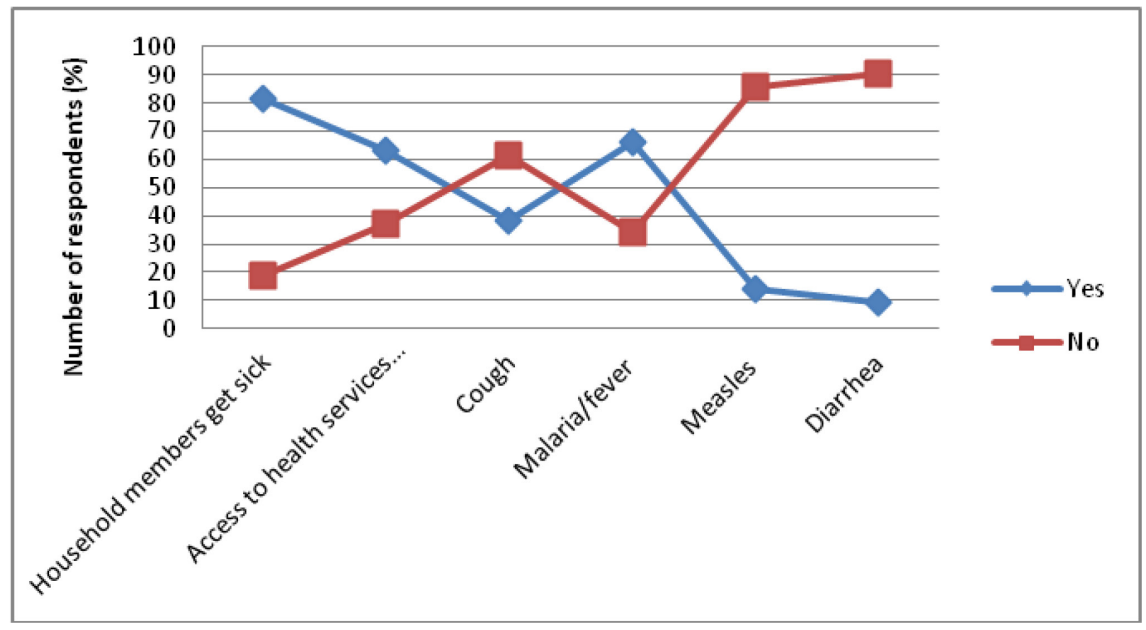

Figure 6: Percentage distribution of respondent's response on the impact of flood on health.

Table 3: Percentage distribution of respondent's response on the impact of flood on water and sanitation.

\begin{tabular}{|l|l|l|}
\hline Variables & Frequency & Percentage \\
\hline Common source of drinking water & 18.3 \\
\hline Borehole & 92 & 21.1 \\
\hline Protected well & 106 & 16.5 \\
\hline Unprotected well & 83 & 25.5 \\
\hline River & 128 & 4.2 \\
\hline Spring & 21 & 14.3 \\
\hline $\begin{array}{l}\text { Sachet/bottled } \\
\text { water }\end{array}$ & 72 & 100.0 \\
\hline Total & 502 & 86.9 \\
\hline Source of water affected by the flood & 13.1 \\
\hline Yes & 436 & 100.0 \\
\hline No & 66 & 10.0 \\
\hline Total & 502 & 69.5 \\
\hline Types of sanitary facilities available & 18.9 \\
\hline Vip & 50 & 1.6 \\
\hline $\begin{array}{l}\text { Traditional pit } \\
\text { latrine }\end{array}$ & 349 & 100.0 \\
\hline $\begin{array}{l}\text { Reticulated } \\
\text { sewerage }\end{array}$ & 95 & 95.2 \\
\hline Others & 8 & 4.8 \\
\hline Total & 502 & 100.0 \\
\hline Our sanitary facilities affected by the flood water & \multicolumn{2}{|l|}{} \\
\hline Yes & 478 & 24 \\
\hline No & 502 & \\
\hline Total &
\end{tabular}




\section{Conclusions and recommendations}

Flood waters carry nutrients and sediments, which are deposited on flood plains, enriching the soil reducing or obviating the need for nourishment through artificial fertilizers. Inundated areas retain soil moisture that helps raise crops without irrigation. Rice paddies are sometimes flooded deliberately to take advantage of this natural fertilization process. A river basin is an ecological unit interconnecting spawning habitats with rearing habitats for a variety of species and other aquatic systems. Seasonal habitats on the flood plain, created by variable flow regimes, are essential for various stages of the life cycle of species. Floods provide an ecological trigger for both the spawning and migration of certain species.

The river ecosystem is a critical habitat for the biota: fish, wildlife and waterfowl. Seasonal variability and variable sediment and flow regimes help maintain comparably high levels of biodiversity in rivers and flood plains. Wetlands or swamps located in flood plains serve as natural buffer zones for excessive flood flows and play host to many birds, fish and plants. Those areas can provide a number of ecosystem services and products such as water purification, food and fibre supplies and under certain circumstances (or antecedent conditions) flood mitigation benefits. Supplementary livelihoods in the form of recreational and eco-tourism activities can be made possible by the presence of the rich river ecosystem, bestowed with abundant flora and fauna. Surface runoff and flooding can help wash down pollutants and contaminants deposited on land caused by the intensive use of pesticides and fertilizers. They also flush out accumulated organic substances brought by untreated drainage water from farmlands, stockyards, factories and domestic use and restore the ecological health of stagnant river reaches and streams by diluting them and providing clean water.

However, immediate impacts of flooding include loss of human life, damage to property, destruction of crops, loss of livestock, non-functioning of infrastructure facilities and deterioration of health condition owing to waterborne diseases. Flash floods, with little or no warning time, cause more deaths than slow-rising riverine floods. In monetary terms, the extent of damages caused by floods is on the one hand dependent on the extent, depth and duration of flooding, and the velocities of flows in the flooded areas. On the other hand it is dependent on the vulnerabilities of economic activities and communities. The huge psycho-social effects on flood victims and their families can traumatize them for long periods of time. The loss of loved ones can generate deep impacts, especially on children. Displacement from one's home, loss of property, loss of memorabilia and livelihoods, decreased levels of security in the aftermath of floods and in temporary shelters, and disruption to business and social affairs can cause stress. The stress of overcoming these losses can be overwhelming and produce lasting psychological impacts.

The main conclusion is that most of the flood victims, having gone through serious hardship at their relief camps, felt that life had to continue. They were able to get back to their various houses and start life. While some were able to 
get back to work quickly, some are still finding it difficult to embark into normal life. It is therefore recommended that further study(s) should be conducted on the post flood assessment on the victims and traumatic experiences. Efforts should be made by government to create awareness on early warnings made by metrological departments.

\section{References}

[1] Nasir R., Zainah Z. and Khairudin R. Psychological effects on Victims of the Johor Flood 2006/2007. http://dx.doi.org/10.5539/ass.v8n8p126

[2] Ahern M., Kovats R.S., Wilkinson P., Few R., and Matties F. Global health impacts of flood; epidemiological evidence. Epidemiolic Reviews, 27, 3046. http://dx.doi.org/10.1093/epirev/mxi004

[3] The Nation (2012). The Nation Newspaper, Oct.16th, 2012

[4] Messner F. and Green C. Fundamental issues in the economic evaluation of flood damage. In: Messner F., Penning-Rowsell E., Green C., Meyer V. Tunstall., van der Veen A., Guidelines for socio-economic flood damage, vulnerability evaluation. Floodsite, pp 16-32, 2006

[5] Awopetu R.G. Assessment of Psychological Impact of Flooding: Reports from Two relief Camps in Makurdi, Benue State, Nigeria. Paper presented at 2012 Annual Scientific Conference and General Meeting of the Nigerian Psychological Association (NPA), 2012

[6] Werrity A., Houston D., Ball T., Tavendale A., and Black A. Exploring social impacts of flood risk and flooding in Scotland. School of social sciences - geography. University of Dundee, Scottish government, pp 157, 2007

[7] Grinwis M., Duyck M. Integratie van de problematic van de hoogwaterstanden en overstromingen in een socio-economische context: overstrominsellende. K.I.N.T. Brussel pp. 611, 2000

[8] National Population Census. Federal Republic of Nigeria Official Gazette. No. 4. Lagos 19 January 2007, Vol. 94, 2006

[9] Strydom H., Fouche C.B. and Delport C.S.L. Research at Grassroots for Social Sciences and Human Service Professions. Third edition. 2005 